\title{
A STUDY OF THE MOTOR FITNESS OF STUDENTS AGED 12-13
}

\author{
Petia Dikova \\ National Sports Academy „Vassil Levski”, Sofia, Bulgaria
}

\begin{abstract}
The problem of motor fitness of school students continues to be of major importance up to date. The attempts of educational institutions to prepare and implement in practice tests for the assessment of the basic motor skills - speed, strength and endurance are commendable, but in our opinion, this is a process that must be carried out over time. The main role and merit should be given to teachers of physical education and sport, who apply innovative approaches in the learning process.

The purpose of this study is to improve the mobility of 12-13-year-old pupils. The teaching units of the school program in physical education and sport included an additional set of complex exercise aiming at improvement of students' physical activity for a period of 7 months.

The results obtained from the pedagogical experiment lead us to conclude that our exercises and their distribution in the physical education and sport classes show high efficiency in the complex development of motor skills with 12-13-year-old students in our research, improving their motor fitness.
\end{abstract}

Key words: physical fitness, students, motor skills

\section{INTRODUCTION}

Physical education is a multifaceted pedagogical process that helps for specific tasks to be solved, primarily related to the improvement of students' health, motor skills and habits. The changes that have taken place in recent years put the work of physical education and sport teachers to a serious test. The lack of sufficient and well-equipped facilities in schools, the busy school programs, the reduction of classes in physical education and sport, the closing of a large number of sports schools and sports sections in schools have led to limitation of opportunities for aimed physical activity of students. All this has a negative effect on students' lifestyle and is directly related to the expanding hypodynamia.

Hypodynamia is the main reason for a number of socially significant illnesses in childhood and adolescence - spinal distortions, high blood pressure, diabetes, etc., which have a negative impact on their lives as a whole.

Adding the bad habits acquired in childhood and adolescence, which are difficult to get out of later, inevitably leads to serious health problems in adulthood.
That is why one of the main tasks of the physical education and sport activities is to preserve and strengthen students' health, which, in turn, is a reflection of their mental health and motor fitness.

\section{METHODOLOGY}

To prove our assumption that increasing the intensity in the physical education and sport lesson through additional exercises with various effects will lead to an improvement in the general physical qualities of the students in the experimental group, which in turn will have a positive effect on their motor fitness, we conducted a 7-month pedagogical experiment.

49 students from $19^{\text {th }}$ Secondary school "Elin Pelin" in Sofia city participated in the study. They were divided into two groups - experimental (25 students) and control (24 students). To accomplish this, we used the general physical training program we developed for our previous study, which included sets of motor activities with different orientation, which we included in the lesson of physical education and sport for seven months (Milanova, 2013).

The Sports-pedagogical testing was performed using the following benchmarks (Table 1). 
Table 1. Indicators studied

\begin{tabular}{|l|c|c|}
\hline \multicolumn{1}{|c|}{ NAME OF THE TEST } & MEASURING UNITS & MEASUREMENT ACCURACY \\
\hline $\mathbf{3 0}$ m running - standing start position - 30 $\mathbf{m}$ & Seconds & up to $0.01 \mathrm{sec}$ \\
\hline Standing long jump with two legs - SLJ & Centimeters & up to $0.01 \mathrm{sec}$ \\
\hline $\begin{array}{l}\text { Throwing a heavy ball }-\mathbf{3} \text { kg with two hands } \\
\text { over his/her head - THB }\end{array}$ & Centimeters & up to $1 \mathrm{~cm}$ \\
\hline Agility test - AT & Seconds & up to $0.01 \mathrm{sec}$ \\
\hline $\begin{array}{l}\mathbf{2 0 0} \text { m running - standing } \\
\text { start position (Shuttle Run) - } \mathbf{2 0 0} \mathbf{m}\end{array}$ & Seconds & up to $1 \mathrm{~cm}$ \\
\hline
\end{tabular}

The aim of this study is to improve the motor fit- Research Methods:

ness of 12-13-year old students.

1. Pedagogical experiment.

To accomplish this, we set the following tasks to 2. Sport-pedagogical testing. solve:

3. Mathematical-statistical methods.

1. To put into practice the developed sets of exercises with common impact.

2. To monitor and analyze the dynamics of the results of the control exercises during the experiment.

\section{RESULTS ANALYSIS}

After the carried out seven-month sport-pedagogical experiment, we submitted the data from the control measurements to mathematical to mathematical - statistical processing.

3. To determine the influence of the conducted Table. 2 and Table. 3 present the results of the variaexperiment on the motor fitness of the studied 12-13-year old students. tional analysis of the experimental group (EG) and control group (CG).

Table 2. Initial data from the variational analysis of $E G$

\begin{tabular}{|c|c|c|c|c|c|c|c|c|c|}
\hline & $\mathrm{n}$ & $\mathrm{X}$ min & Xmax & $\mathbf{R}$ & $\overline{\mathrm{X}}$ & S & $\mathbf{V}$ & As & $\mathbf{E x}$ \\
\hline $30 \mathrm{~m}$ & 25 & 4,78 & 6,76 & 1,98 & 5,5084 & 0,49 & 8,81 & 0,826 & 0,534 \\
\hline SLJ & 25 & 100 & 220 & 120 & 165 & 28,58 & 17,32 & $-0,199$ & $-0,196$ \\
\hline THB & 25 & 240 & 650 & 410 & 427 & 112,65 & 26,38 & $-0,037$ & $-0,458$ \\
\hline AT & 25 & 38,04 & 56,9 & 18,86 & 43,9536 & 3,52 & 8,01 & 1,994* & $7,093 *$ \\
\hline $200 \mathrm{~m}$ & 25 & 12,81 & 22,86 & 10,05 & 15,8152 & 2,27 & 14,33 & $1,437^{*}$ & $2,584 *$ \\
\hline
\end{tabular}

Table 3. Initial data from the variational analysis of $C G$

\begin{tabular}{|c|c|c|c|c|c|c|c|c|c|}
\hline & $\mathbf{n}$ & $\mathrm{X} \min$ & Xmax & $\mathbf{R}$ & $\bar{X}$ & $\mathbf{S}$ & $\bar{V}$ & As & Ex \\
\hline $30 \mathrm{~m}$ & 24 & 5,06 & 7,84 & 2,78 & 5,8070833 & 0,74 & 12,69 & $1,703 *$ & 3,034 * \\
\hline SLJ & 24 & 138 & 219 & 81 & 168,66667 & 23,33 & 13,83 & 0,507 & $-0,505$ \\
\hline THB & 24 & 260 & 640 & 380 & 413,33333 & 99,99 & 24,19 & 0,289 & $-0,291$ \\
\hline AT & 24 & 37,86 & 58,2 & 20,34 & 45,875 & 5,41 & 11,79 & 0,677 & 0,23 \\
\hline $200 \mathrm{~m}$ & 24 & 12,71 & 18,52 & 5,81 & 15,460417 & 1,55 & 10,01 & 0,362 & $-0,359$ \\
\hline
\end{tabular}

At the beginning of the experiment, there were critical ones for $\mathrm{n}=25$ (As $=0.927$ and $\mathrm{Ex}=1.803$ ). no significant differences between the two studied In the CG, differences are observed only with the groups. The initial data show that for the EG only $30 \mathrm{~m}$ running test.

for two of the indicators the result is strongly ho- At the end of the experiment, all values of As and mogeneous (30 m and $200 \mathrm{~m}$ running), while for all Ex were below the critical value, which indicates other indicators, including those of CG it is average a symmetrical distribution with normal excess, homogeneous. The distribution for the first three and the coefficient of variation shows a downward indicators at the EG is symmetrical, with normal trend (Table 4 and Table 5).

$\mathrm{Ex}$, while for the $200 \mathrm{~m}$ running and the agility test

the differences are significant with values above the This gives us ground to accept that the experiment 
we conducted had a positive impact on the dyna- mics of the motor qualities of the EG students.

Table 4. Variational data analysis for EG at the end of the experiment

\begin{tabular}{|l|l|l|l|l|l|l|l|l|l|}
\hline & \multicolumn{1}{|c|}{$\mathbf{n}$} & $\mathbf{X} \mathbf{m i n}$ & $\mathbf{X} \max$ & \multicolumn{1}{c|}{$\mathbf{R}$} & \multicolumn{1}{c|}{ X } & \multicolumn{1}{c|}{ S } & \multicolumn{1}{c|}{ V } & \multicolumn{1}{c|}{ As } & \multicolumn{1}{c|}{ Ex } \\
\hline $\mathbf{3 0} \mathbf{~ m}$ & 25 & 4,2 & 6,05 & 1,85 & 5,0688 & 0,44 & 8,61 & 0,571 & 0,084 \\
\hline SLJ & 25 & 155 & 250 & 95 & 196,4 & 22,15 & 11,28 & 0,582 & 0,306 \\
\hline THB & 25 & 380 & 690 & 310 & 496 & 83,37 & 16,81 & 0,68 & $-0,042$ \\
\hline AT & 25 & 38,86 & 46,72 & 7,86 & 42,6176 & 1,60 & 3,75 & $-0,12$ & 1,323 \\
\hline $\mathbf{2 0 0} \mathbf{~ m}$ & 25 & 12,64 & 15,75 & 3,11 & 14,6996 & 0,85 & 5,77 & $-0,899$ & 0,114 \\
\hline
\end{tabular}

Table 5. Variational data analysis for the CG at the end of the experiment

\begin{tabular}{|c|l|l|l|l|l|l|l|l|l|}
\cline { 2 - 9 } \multicolumn{1}{c|}{} & \multicolumn{1}{c|}{$\mathbf{n}$} & $\mathbf{X} \mathbf{m i n}$ & $\mathbf{X} \mathbf{m a x}$ & \multicolumn{1}{c|}{$\mathbf{R}$} & $\overline{\mathbf{X}}$ & $\mathbf{S}$ & $\mathbf{V}$ & \multicolumn{1}{c|}{ As } & Ex \\
\hline $\mathbf{3 0} \mathbf{~ m}$ & 24 & 4,87 & 7,64 & 2,77 & 5,59375 & 0,72 & 12,91 & $1,617 *$ & $2,634^{*}$ \\
\hline SLJ & 24 & 142 & 225 & 83 & 175,83333 & 22,53 & 12,82 & 0,432 & $-0,399$ \\
\hline THB & 24 & 265 & 655 & 390 & 419,58333 & 99,43 & 23,70 & 0,371 & $-0,098$ \\
\hline AT & 24 & 37,64 & 58,04 & 20,4 & 45,727083 & 5,43 & 11,87 & 0,689 & 0,257 \\
\hline $\mathbf{2 0 0} \mathbf{m}$ & 24 & 12,68 & 18,46 & 5,78 & 15,345 & 1,55 & 10,10 & 0,389 & $-0,336$ \\
\hline
\end{tabular}

The comparative analysis shows an improvement in cant improvement in the development of strength, the results for all control exercises. A significant in- speed, endurance and agility of the students in crease in the level of the basic motor skills has been the EG. The students from the CG also showed an achieved at the time of the aimed overall impact on increase in the development of the basic physical the physical qualities of the EG students.

qualities but compared with that of the EG, it was At the end of the experiment, there was a signifi- insignificant (Fig. 1).

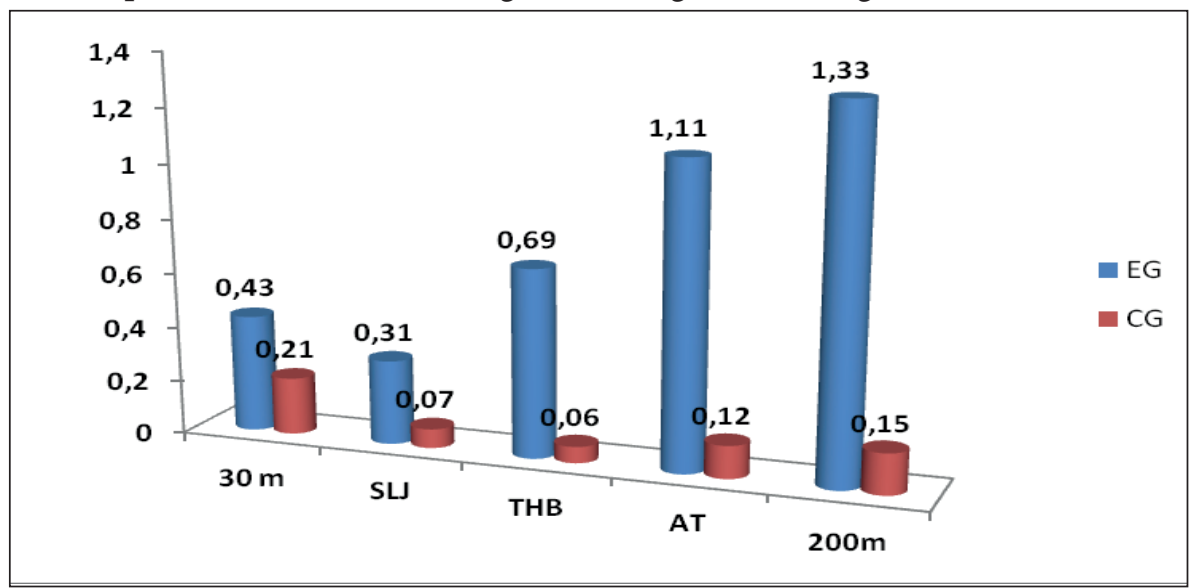

Figure 1. Increase in the results of the control exercises at the end of the experiment

It is well known that the the most sensitive periods for the development of speed-power qualities and speed are at the age of $10-15$, ie. the period of puberty. The rate of increase in speed and speed-power capabilities during the experiment confirm the studies that the age of 12 or 13 is very favorable for the basic motor qualities to be formed.

These results indicate the correctness of our choice to include additional sets of physical exercises with general physical impact in the PE lesson. They support the mobilization and adaptation processes not only in the physical but also in the psychological and physiological development of 12-13-year old students. They also help to expand the range of motor skills and technical skills, which has a significant impact on the performance and the result from the control exercises requiring a certain degree of technical skills.

\section{COMPARATIVE ANALYSIS OF RESULTS BY} GENDER

The analysis of the results by gender revealed that there were significant differences in motor fitness 
between boys and girls of the EG at this age, despite some isolated cases (Figure 2). At the end of the 7-month period, values with especially high increase were measured in:

$\checkmark 30$ m running (girls -0.49 sec; boys -0.39 sec);

$\checkmark 200 \mathrm{~m}$ running $(2.05 \mathrm{sec}$ girls and $0.68 \mathrm{sec}$ boys);

$\checkmark$ Standing long jump - the improvement of the explosive power in legs with girls was 34.59 $\mathrm{cm}$ and with boys $28.46 \mathrm{~cm}$.

Throwing a heavy ball - that gives information about the strength and explosive power in hands, shows an upward trend with girls, with an increase of $95 \mathrm{~cm}$, while with boys the increase is $45 \mathrm{~cm}$.

The same tendency is observed in the agility test. The girls manage to achieve a result which is 2 seconds better than the one at the beginning of the study, while the improvement with the boys is of $0.28 \mathrm{sec}$.

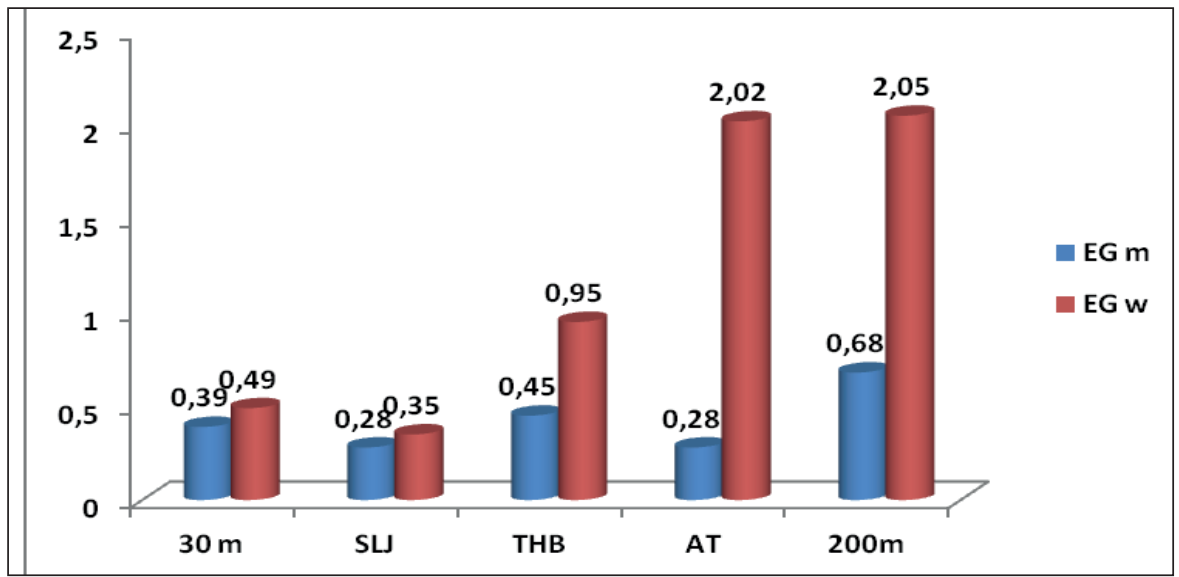

Figure 2. Increase in the result of the control exercises for the EG separately for boys and girls

Most probably the acceleration processes that are the recovery processes, the knowledge of which is more pronounced at this age in girls are relevant a prerequisite for effective impact on children's and to their better performance. The condition of the adolescents' organism with physical exercises.

cardiovascular, respiratory, muscular, autonomic For students in the CG, the differences between and central nervous systems at the time of puberty boys and girls are so insignificant that we can acis also relevant. This is the period during which the cept them as non-existent (Figure 3).

dynamics in the mobility and lability of the nervous processes is the greatest for both genders, and The great differences between the EG and the CG they, in turn, are responsible for the speed of mus- for all control exercises are generally attributed to cle contractions. These conditions are inextricably the additional impact applied on the EG students linked to the adaptation processes associated with in their PE classes.

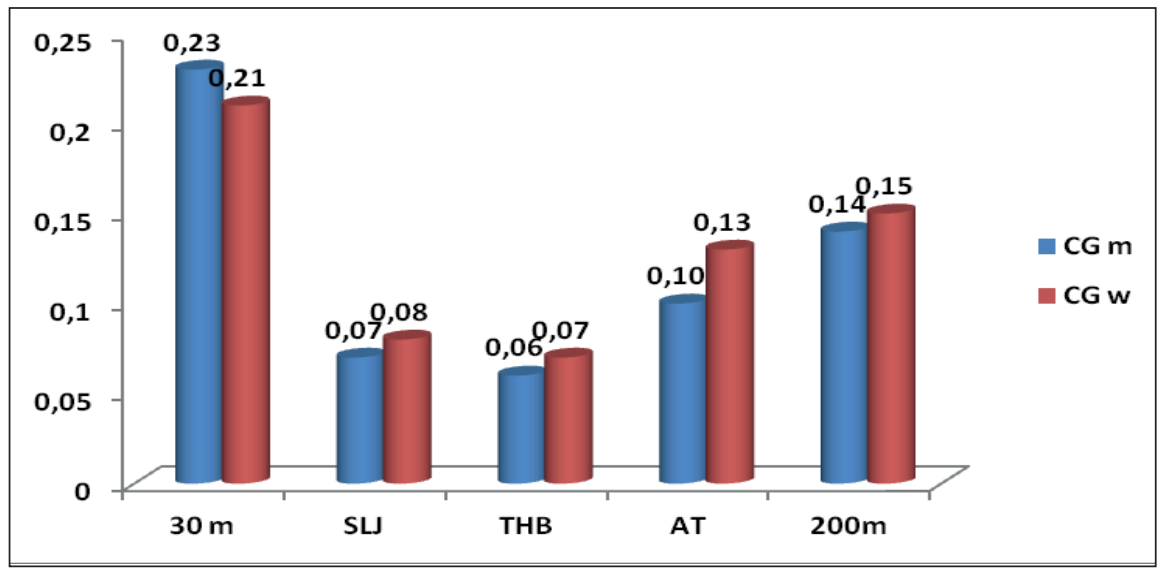

Figure 3. Increase in the result of the control exercises for the CG separately for boys and girls 


\section{CONCLUSION}

The results of the experiment confirm the usefulness of additional exercises as a number and intensity in the PE lesson. The increase in the speed and speed-power capabilities of the EG students over the course of the experiment is very significant and gives us a reason to believe that there are still undiscovered opportunities regarding the improvement of effectiveness in the PE lesson.

The set of motor exercises thus applied may be updated and adapted to different school grades in our future larger-scale studies.

\section{REFERENCES}

Dimitrova, N. (2007). Sravnitelen analiz za otsenka na tendentsiite $\mathrm{v}$ razvitieto na skorostnite vuzmojnosti na detsa ot preduchlishtna vuzrast. Sport i nauka. Izv. br.1. Sofia.

Dimitrova, N., Nasiev, Er., Pavlov, Hr. (2017). Kolichestvena otsenka na fizicheskata godnost $\mathrm{v}$ nachalna uchilishtna vuzrast. Predizvikatelstva i perspektivi pred sportnata nauka. Spetsifika na podgotovkata $v$ razlichni sportni distsiplini. Pp.197-204. Sofia.

Dimitrova. N. (2007). Tendentsii i sravnitelen analiz na razvitieto na vzrivnata sila na detsa ot preduchilishta vuzrast. Sport i nauka. Izv. br.1. Sofia.

Manolova, A., Tsolova, G. (2007). Dvigatelnata aktivnost - riskov i prevantiven factor za povishenoto arterialno naliagane. Sport i nauka. 1.

Manshonov, N. (2005). Znachenieto na fizicheskata aktivnost za opazvane i ukrepvane na psihicheskoto zdrave na podrastvashtite. Fizikalna meditsina, rehabilitatsia, $z$ drave. 4.

Merdjanov, Ch. (1995). Edno komprometirashto purvenstvo. Universitetsko izdanie "Sv. Kliment Ohridski". Sofia.

Milanova, P. (2013). Stil na jivot i zdraven status na podrastvashti. Prilojenie 2. Disertatsia. Sofia.

Ramshev, K. (2004). Arterialna hipertonia i nadnormeno telesno teglo v mladejka vuzrast. BM. LVI.

Tsonevski, D. (2001). Hipokineziata I neratsionalnoto hranene kato vodeshti faktori na riskovoto povedenie za zdraveto - medikosotsialni aspekti. Sotsialna meditsina. 9.

Zlatev, Zl., Stayanov, B. (2006). Kum problema za dvigatelnite sposobnosti - harakterni osobenosti, spetsifika na proiavlenie, izmervane. Sbornik dokladi ot IV natsionalna nauchno-prakticheska konferentsia "Fizichesko vuzpitanie I sport v uchilishte". Varna.

\section{Corresponding author:}

Petia Dikova

Department Heavy athletics, boxing, fencing and sport for all National Sports Academy "Vassil Levski" Studentski grad, 21, Acad. Stefan Mladenov str. Sofia 1700, Bulgaria E-mail: petiamilanova@gmail.com 